\title{
The middle to late Eocene evolution of nummulitid foraminifer Heterostegina in the Western Tethys
}

György Less, Ercan Özcan, Cesare A. Papazzoni, and Rudolf Stockar

Acta Palaeontologica Polonica 53 (2), 2008: 317-350 doi:http://dx.doi.org/10.4202/app.2008.0212

Megalospheric forms of Western Tethyan late Bartonian to late Priabonian involute Heterostegina from numerous localities, marking different ecological conditions, were morphometrically investigated. They belong to three species, $H$. armenica, $H$. reticulata, and $H$. gracilis based on the presence/absence of granulation, on the chamberlet characteristics and on the relative size of proloculus. Within these species a very rapid evolution could be observed in the reduction of the number of operculinid chambers, in the increase of the number of chamberlets and partially in the increase of the proloculus size. This evolution is demonstrated by stratigraphic superpositions in several localities (especially in the Mossano section), and is supported also by the change of co-occurring fossils, starting with the disappearance of large-sized Nummulites, then followed by the appearance of the genus Spiroclypeus and then by the disappearance of orthophragmines of middle Eocene acme. Based on the reduction of operculinid chambers, two chronosubspecies of Heterostegina armenica and seven of $H$. reticulata are defined biometrically (four of them: $H$. armenica tigrisensis, $H$. reticulata tronensis, $H$. $r$. hungarica, and H. r. mossanensis are introduced here). This allows to subdivide the Shallow Benthic Zone (SBZ) 18 into three and SBZ 19 into two subzones. The extremely rapid evolution of $H$. reticulata allows to calibrate larger foraminiferal events around the middle/late Eocene boundary. The extinction of large-sized Nummulites seems to be heterochronous in the late Bartonian in having migrated eastward, while the first appearance of Spiroclypeus is shown to be synchronous at the base of the Priabonian. The middle/upper Eocene (= Bartonian/Priabonian) boundary is to be placed at the base of the Priabona marls in the Mossano section corresponding to the SBZ 18/19 limit, to the first appearance of genus Spiroclypeus , to that of Nummulites fabianii and of Heterostegina reticulata mossanensis. It falls into the upper part of both the P 15 and NP 18 planktic zones. The Western Tethyan Eocene involute Heterostegina became extinct, apparently with no Oligocene successors.

Key words: Foraminifera, Nummulitidae, Heterostegina, biometry, evolution, stratigraphy, Eocene

György Less [foldlgy@uni-miskolc.hu], University of Miskolc, Department of Geology and Mineral Resources, H-3515, Miskolc-Egyetemváros, Hungary; Ercan Özcan [ozcanerc@itu.edu.tr], Department of Geology, Faculty of Mines, Istanbul Technical University, Ayazaga/Istanbul 34469, Turkey; Cesare A. Papazzoni [papazzoni@unimore.it 
], Dipartimento di Scienze della Terra, Università di Modena e Reggio Emilia, Largo S. Eufemia 19, I-41100 Modena, Italy; Rudolf Stockar [rudolf.stockar@ti.ch], Museo cantonale di storia naturale, Viale Carlo Cattaneo 4, CH-6900 Lugano, Switzerland.

This is an open-access article distributed under the terms of the Creative Commons Attribution License (for details please see creativecommons.org), which permits unrestricted use, distribution, and reproduction in any medium, provided the original author and source are credited.

FoF 